\title{
Experimental infection in Notodiaptomus sp. (Crustacea: Calanoida) with larvae of Camallanus sp. (Nematoda: Camallanidae)
}

\author{
[Infecção experimental em Notodiaptomus sp. (Crustacea: Calanoida) com larvas de \\ Camallanus sp. (Nematoda: Camallanidae)]

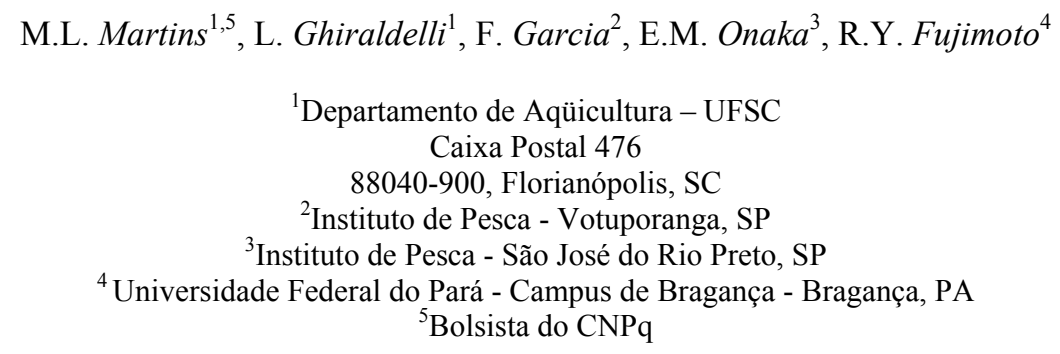

\begin{abstract}
This trial registered the experimental infection viability with nematode larvae Camallanus sp. in Notodiaptomus sp., a crustacean, which can be an intermediate host. Adult females of nematode were dissected from the intestines of Xiphophorus maculatus (Osteichthyes: Poeciliidae), at a fish farm in the State of São Paulo. Females were slightly compressed for larvae release, collected with Pasteur pipette and separated on Petri dishes with $9 \mathrm{ml}$ filtered water at $28.1^{\circ} \mathrm{C}$, from zooplankton culture. Treatments consisted of Petri dishes with 60 and 105 copepods, in which 120, 150 and 210 larvae of nematode were added in four replications. Twenty-four and $36 \mathrm{~h}$ after exposition to the larvae, the copepods were fixed in $70 \%$ alcohol to record the amount of fixed larvae. Twenty four hours after exposition, 60 copepods group with 120 larvae showed significantly higher prevalence (46.5\%) when compared to 105 copepods and 120 larvae (33.2\%). Thus, these answers suggested that 120 larvae were enough for a successful infectivity. Experimental infection was available and so, it was used as a pattern to life cycle studies of camallanid nematodes and hosts susceptibility tests.
\end{abstract}

Keywords: experimental infection, Nematoda, Camallanus, Crustacea, Notodiaptomus

\section{RESUMO}

A viabilidade da infecção experimental com larvas do nematóide Camallanus sp. em Notodiaptomus $s p$., crustáceo com potencial para hospedeiro intermediário foi avaliada. Fêmeas adultas do nematóide foram extraídas de Xiphophorus maculatus (Osteichthyes: Poeciliidae), provenientes de piscicultura de peixes ornamentais no estado de São Paulo. As fêmeas foram ligeiramente pressionadas para liberar as larvas, coletadas com pipeta Pasteur e separadas em placas de Petri contendo $9 \mathrm{ml}$ de água filtrada a $28,1^{\circ} \mathrm{C}$ do próprio cultivo de zooplâncton. Os tratamentos consistiram de placas contendo 60 e 105 copépodes onde se adicionou 120, 150 e 210 larvas de nematóides em quatro repetições. Nos tempos de 24 e $36 \mathrm{~h}$ após a exposição às larvas, os copépodes foram fixados em álcool 70\% para quantificação de larvas. Após $24 \mathrm{~h}$ de exposição, o grupo com 60 copépodes na presença de 120 larvas apresentou maior prevalência $(46,5 \%)$ do que 105 copépodes com 120 larvas (33,2\%). Sugere-se que 120 larvas foram suficientes para o sucesso da infecção. A infeç̧ão experimental mostrou-se viável, servindo de modelo para o estudo do ciclo de vida de camalanideos e testes de susceptibilidade de hospedeiros.

Palavras-chave: infecção experimental, Nematoda, Camallanus, Crustacea, Notodiaptomus

Recebido em 26 de setembro de 2005

Aceito em 3 de janeiro de 2007

E-mail: mlaterca@cca.ufsc.br 


\section{INTRODUCTION}

The activity of ornamental fish has presented significant increase, but little information is known about the parasites that impair the fish production. Evans and Lester (2001) estimated the ornamental fish industry in 900 million dollars since the national and international transport of fishes is responsible for diseases dissemination. The presence of parasites in ornamental fish was registered in China (Kuo et al., 1994), Germany (Moravec et al., 1999), Australia (Evans and Lester, 2001), Korea (Kim et al., 2002) and Sri Lanka (Thilakaratne et al., 2003). In Hawaii, the introduction of exotic poeciliid fishes has caused dispersion of exotic parasites such as Camallanus cotti Fujita, 1929 with $65.2 \%$ prevalence rate in Poecilia reticulata Peters, 1859 (Vincent and Font, 2003).

In river as Negro, here in Amazonia - Brazil, Ferraz (1999) reported the parasitic diseases as the main obstacle to the success of exporting ornamental fishes, which are controlled with prophylactic methods. In a survey of parasitic fauna of Xiphophorus sp., reared in the State of São Paulo, Garcia et al. (2003) pointed out the importance of ectoparasites as a result of inappropriate fish handling. On the other hand, there are some endoparasites that have not yet shown significant importance on Brazilian freshwater food fish (Martins et al. 2002), but their occurrence in the ornamental industry may impair rearing success, which reaches $88.5 \%$ of prevalence (Kim et al., 2002). Nematodes of the genus Camallanus Railliet and Henry, 1915 are widely distributed over the world in cultured fish for consumption or as ornament (Torres et al., 1991; Lakshimi et al., 1990; Ferraz and Thatcher, 1990; Moravec et al., 1999). This fact increases the prevalence rate up to $80 \%$ due to the salmonids (Torres et al., 1990) and $P$. reticulata (Kim et al., 2002).

Camallanids have, in general, a microcrustacean as an intermediate host. Their life cycle has been studied in copepods (Stromberg and Crites, 1974; Bashirullah and Ahmed, 1976; De et al., 1986), amphipods (Moravec, 1996) and cladocerans (Moravec et al., 1998). In laboratory conditions, Campana-Rouget (1961), Stromberg and Crites (1974), Bashirullah and Ahmed (1976) and De et al. (1986) studied the infection rate and the life cycle evolution of camallanid larvae in microcrustaceans.

Due to the importance of this nematode in ornamental fish reared and commercialised in Brazil, this trial took into account the viability of experimental infections with larvae of Camallanus sp. (Nematoda: Camallanidae) in Notodiaptomus sp. (Crustacea: Calanoida), a microcrustacean commonly found in ponds, but with potential of being an intermediate host in nematode's life cycle.

\section{MATERIAL AND METHODS}

Copepods, used in this trial, were from the Zooplankton Culture Laboratory, Aquaculture Centre, UNESP, Jaboticabal, SP, in November 2001. The nematode's larvae were recovered from the adult females of Xiphophorus maculatus Günther, 1866 (Osteichthyes: Poeciliidae). Forty fish specimens were given from the fish farm, called Brejo Grande Ltda, in Araraquara - SP, with $0.5 \pm 0.1 \mathrm{~g}$ mean weight, maintained on Petri dishes with saline solution to dissect their intestines.

Pregnant females of nematode were separated and slightly compressed, so that the larvae could be released, collected with pipette Pasteur and separated on Petri dishes with $9 \mathrm{ml}$ filtered water at $28.1^{\circ} \mathrm{C}$, from the zooplankton culture. The experimental unities consisted of Petri dishes with 60 and 105 copepods in which 120, 150 and 210 larvae of nematodes were added in four replications. Twenty-four and $36 \mathrm{~h}$ after exposition to the larvae, the copepods were fixed in $70 \%$ alcohol to record the amount of fixed larvae. Copepods were mounted between glass and coverslip with a drop of Amann's lactofenol for clarification. Prevalence and mean intensity of nematode in the crustaceans were calculated according to Bush et al. (1997). For statistical analysis, by comparing the times after infection and the mean number of larvae in each treatment, it was applied the Sigma Stat, from Jandel Corporation (Zar, 1996).

\section{RESULTS AND DISCUSSION}

There was no significant difference $(\mathrm{P}>0.05)$ between 60 and 105 infected copepods $36 \mathrm{~h}$ after 
the exposition to the larvae. On the other hand, during the $24 \mathrm{~h}$ exposition treatment, 60 copepods with 120 larvae showed significantly higher prevalence $(46.5 \%)$ when compared to 105 copepods and 120 larvae (33.2\%). Twenty four hours after being observed, the infective larvae did not show difference with 60 and 105 copepods treatments. The comparison of the larvae infection did not show significant difference $(\mathrm{P}>0.05)$, suggesting that 120 larvae were enough to cause a successful infection (Table 1, Fig. 1). The $36 \mathrm{~h}$ treatments exposition with 60 copepods and 150 larvae as well as with 105 copepods and 120, 150 and 210 larvae showed several numbers of empty copepods, which suggests their deaths.

Table 1. Evaluation of the experimental infection of Notodiaptomus sp. with larvae of Camallanus sp., 24 and 36 hours after infection. Different letters indicate significant difference $(\mathrm{P}<0.05)$ in the prevalence within each time

\begin{tabular}{lcccc}
$\begin{array}{l}\text { Time } \\
(\mathrm{h})\end{array}$ & $\begin{array}{c}\text { Number of } \\
\text { infected copepods }\end{array}$ & $\begin{array}{c}\text { Number } \\
\text { of larvae }\end{array}$ & $\begin{array}{c}\text { Prevalence } \\
(\%)\end{array}$ & $\begin{array}{c}\text { Mean intensity } \\
\text { (range) }\end{array}$ \\
\hline \multirow{3}{*}{60} & 210 & $46.42 \mathrm{a}$ & $1.65 \pm(0-4)$ \\
& & 150 & $47.91 \mathrm{a}$ & $1.28 \pm(0-2)$ \\
& & 120 & $46.46 \mathrm{a}$ & $1.16 \pm(0-3)$ \\
\cline { 2 - 4 } & \multirow{2}{*}{105} & 210 & $45.07 \mathrm{a}$ & $1.24 \pm(0-4)$ \\
& & 150 & $30.25 \mathrm{a}$ & $1.16 \pm(0-3)$ \\
& & 120 & $33.19 \mathrm{~b}$ & $1.14 \pm(0-2)$ \\
\hline \multirow{3}{*}{60} & 210 & $48.78 \mathrm{a}$ & $1.66 \pm(0-4)$ \\
& & 150 & $44.29 \mathrm{a}$ & $1.44 \pm(0-4)$ \\
& & 120 & $47.16 \mathrm{a}$ & $1.53 \pm(0-3)$ \\
\hline \multirow{2}{*}{105} & 210 & $70.63 \mathrm{a}$ & $1.61 \pm(0-3)$ \\
& & 150 & $36.05 \mathrm{a}$ & $1.44 \pm(0-3)$ \\
& & 120 & $33.43 \mathrm{a}$ & $1.27 \pm(0-3)$ \\
\hline
\end{tabular}

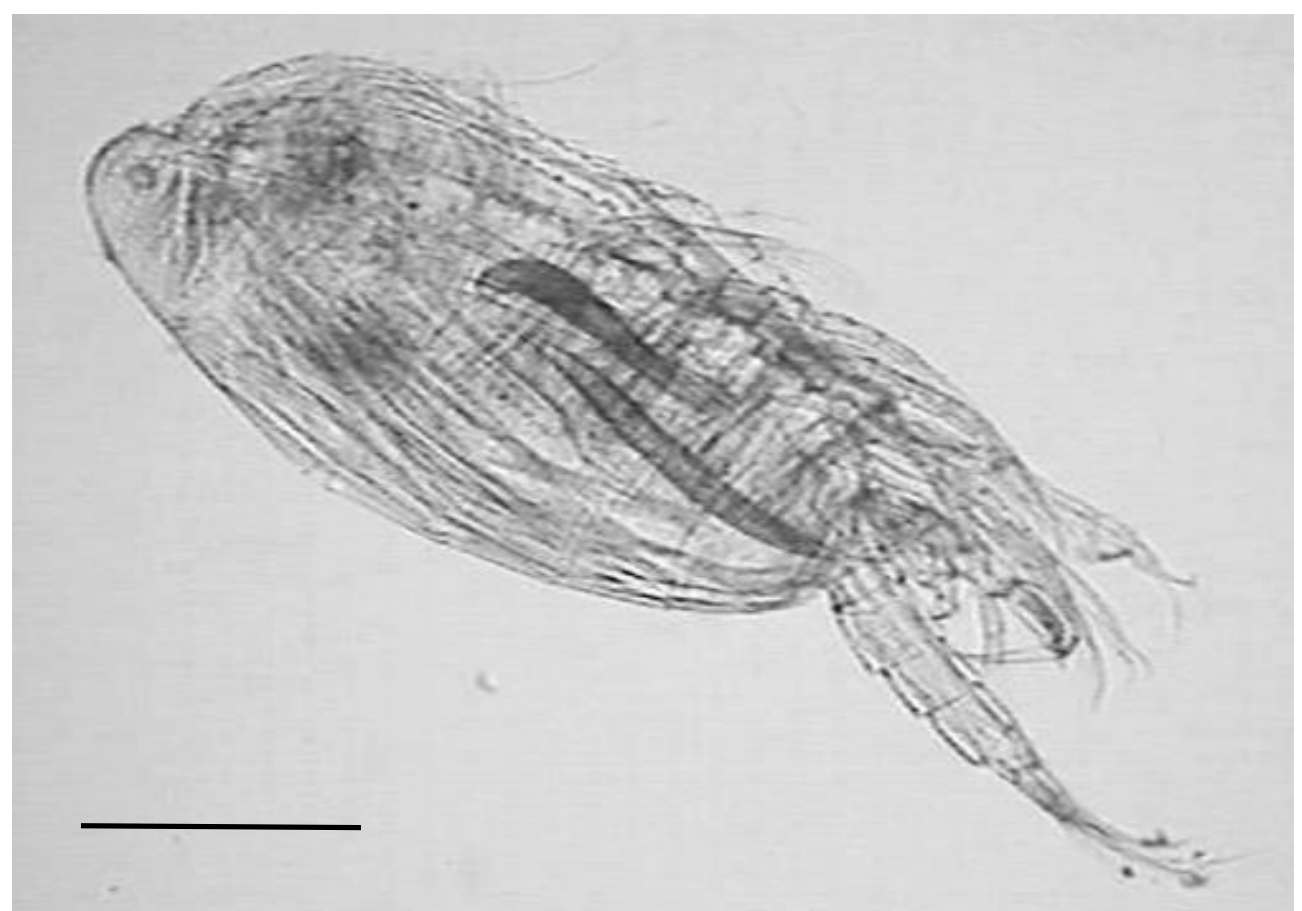

Figure 1. Larvae of Camallanus sp. in the cavity of Notodiaptomus sp. experimentally infected. Scale bar: $100 \mu \mathrm{m}$. 
The recent development of ornamental fish industry, not only for exportation but also to supply the home market, has attracted the attention of researchers and entrepreneurs. As related by Martins et al. (2002) and Garcia et al. (2003), water quality, when it is handling improper and the lack of prophylactic methods are the sources for parasite dispersion.

Stromberg and Crites (1974) and De et al. (1986) have suggested in previous trials that, the copepods should be maintained into filtered water from the zooplankton culture during the essay. Stromberg and Crites (1974) observed a better survival of the larvae of Camallanus oxycephalus Ward and Magath, 1916 at $20^{\circ} \mathrm{C}$ water temperature. Although, it is important to say that, in this study, it was applied a $28.1^{\circ} \mathrm{C}$ temperature, which was the same where the fish and copepods were maintained during the farming.

As reported by Piasecki et al. (2004), the presence of copepods in the aquaculture facilities may cause unfavourable impact due to their role as first intermediate hosts. In this trial, the majority of prevalence rates, varying from 30 to $48.8 \%$, were higher than the one verified by De et al. (1986) in crustacean infected by Procamallanus spiculogubernaculus Agarwal, 1958. Nevertheless, Bashirullah and Ahmed (1976) recorded higher $(90 \%)$ prevalence of crustacean infection with Camallanus adamsi Bashirullah, 1974 than that one observed in this essay (30 to $70.6 \%$ ). These results showed higher prevalence rates when compared to results of Moravec et al. (1998) with Raphidascaris biwakoensis Fujita, 1928.

In spite of a great number of larvae for crustacean infection, no more than four larvae were found into Notodiaptomus sp. These findings were lower than that one registered in Cyclops sp. infected by $C$. oxycephalus (Stromberg and Crites, 1974), but similar to the reported ones in Mesocyclops leuckarti and Thermocyclops crassus (Bashirullah and Ahmed, 1976) as well as in Mesocyclops obsolatus and Mesocyclops oithonoidae (De et al., 1986).

Based on these results, the answers of this study suggest Notodiaptomus sp. as a potential intermediate host for camallanid nematodes, and
$24 \mathrm{~h}$ with 120 larvae as an enough datum to evaluate experimental infection. It is also necessary to highlight the importance of this host that may be found in ponds or in water column that supply fish culture. Further studies might be done to compare different water temperatures in the larval activity to experimental infection and with other microcrustaceans, normally found in ponds.

\section{ACKNOWLEDGEMENTS}

The authors thank CNPq (Conselho Nacional de Desenvolvimento Científico e Tecnológico) and Ana Maria M.A. Vasconcelos for idiom revision.

\section{REFERENCES}

BASHIRULLAH, A.K.M.; AHMED, B. Development of Camallanus adamsi Bashirullah, 1974 (Nematoda: Camallanidae) in cyclopoid copepods. Can. J. Zool., v.54, p.2055-2060, 1976.

BUSH, A.O.; LAFFERTY, K.D.; LOTZ, J.M. et al. Parasitology meets ecology on its own terms: Margolis et al. revisited. J. Parasitol., v.83, p.575583, 1997.

CAMPANA-ROUGET, Y. Remarques sur le cycle évolutif de Camallanus lacustris (Zoega, 1776) et la phylogenie des Camallanidae. Ann. Parasitol., v.36, p.425-434, 1961.

DE, N.C.; SINHA, R.K.; MAJUMDAR, G. Larval development of Procamallanus spiculogubernaculus Agarwal, 1958 (Nematoda: Camallanidae) in copepods. Folia Parasitol., v.33, p.51-60, 1986.

EVANS, B.B.; LESTER, R.J.G. Parasites of ornamental fish imported to Australia. Bull. Eur. Assoc. Fish Pathol., v.21, p.51-55, 2001.

FERRAZ, E. Management and diseases of the ornamental fish exported from the Rio Negro basin. Biol. Trop. Fishes, v.8, p.99-111, 1999.

FERRAZ, E.; THATCHER, V.E. Camallanus acaudatus sp. n. (Nematoda: Camallanidae) e uma descrição do macho de Camallanus tridentatus (Drasche, 1884), parasitas de peixes da Amazônia Brasileira. Amazoniana, v.11, p.135-145, 1990. 
GARCIA, F.; FUJIMOTO, R.Y.; MARTINS, M.L. et al. Parasitismo de Xiphophorus sp. por Urocleidoides sp. e sua relação com os parâmetros hídricos. Bol. Inst. Pesca, v.29, p.123-131, 2003.

KIM, J.-H.; HAYWARD, C.J.; HEO, G.-J. Nematode worm infections (Camallanus cotti, Camallanidae) in guppies (Poecilia reticulata) imported to Korea. Aquaculture, v.205, p.231$235,2002$.

KUO, T.F.; CHUNG, C.D.; HU, T.L. A survey of parasitic diseases from infested aquarium fishes. Mem. Coll. Agric., v.34, p.227-238, 1994

LAKSHIMI, I.R.; RAO, K.H.; SHYAMASUNDARI, K. Camallanus tholukodensis sp. $\mathrm{n}$. from the freshwater cat fish, Mystus seenghala (Sykes) of Tholukodu (Andhra Pradesh). Acta Parasitol. Pol., v.35, p.37-44, 1990.

MARTINS, M.L.; ONAKA, E.M.; MORAES, F.R. et al. Recent studies on parasitic infections of freshwater cultivated fish in the State of São Paulo, Brazil. Acta Scient., v.24, p.981-985, 2002.

MORAVEC, F. The amphipod Gammarus fossarum as natural true intermediate host of the nematode Raphidascaris acus. J. Parasitol., v.82, p.668-669, 1996.

MORAVEC, F.; NAGASAWA, K.; TANAKA, Y. et al. Role of Leptodora kindti (Cladocera: Leptodoridae) in the life cycle of Raphidascaris biwakoensis (Nematoda: Anisakidae), a fish parasite in Lake Biwa, Japan. Dis. Aquat. Org., v.32, p.157-160, 1998.

MORAVEC, F.; WOLTER, J.; KÖRTING, W. Some nematodes and acanthocephalans from exotic ornamental freshwater fishes imported into Germany. Folia Parasitol., v.46, p.296-310, 1999.

PIASECKI, W.; GOODWIN, A.E.; EIRAS, J.C. et al. Importance of copepoda in freshwater aquaculture. Zool. Stud., v.43, p.193-205, 2004.

STROMBERG, P.C.; CRITES, J.L. Population biology of Camallanus oxycephalus Ward and Magath, 1916 (Nematoda: Camallanidae) in white bass in Western Lake Erie. J. Parasitol., v.61, p.123-132, 1974.

THILAKARATNE, I.D.S.I.P.; RAJAPAKSHA, G.; HEWAKOPARA, A. et al. Parasitic infections in freshwater ornamental fish in Sri Lanka. Dis. Aquat. Org., v.54, p.157-162, 2003.

TORRES, P.; CABEZAS, X.; ARENAS, J. et al. Ecological aspects of nematode parasites of introduced salmonids from Valdivia river basin, Chile. Mem. Inst. Oswaldo Cruz, v.86, p.115122, 1991.

TORRES, P.; TEUBER, S.; MIRANDA, J.C. Parasitismo en ecosistemas de agua dulce de Chile. 2. Nematodos parásitos de Percichthys trucha (Pisces: Serranidae) com la descripción de una nueva especie de Camallanus (Nematoda: Spiruroidea). Stud. Neotrop. Fauna Environ., v.25, p.111-119, 1990.

VINCENT, A.G.; FONT, W.F. Host specificity and population structure of two exotic helminth, Camallanus cotti (Nematoda) and Bothriocephalus acheilognathi (Cestoda), parasitizing exotic fishes in Waianu stream, O'Ahu, Hawaii. J. Parasitol., v.89, p.540-544, 2003.

ZAR, J.H. Biostatistical analysis. 3.ed. New Jersey: Prentice-Hall, 1996. 662p. 